\title{
Influence of Apical Patency and Cleaning of the Apical Foramen on Periapical Extrusion in Retreatment
}

Marili Doro Andrade Deonizio', Gilson Blitzkow Sydney' ${ }^{1}$ Antonio Batista', Roberto Pontarolo², Paulo Ricardo Bittencourt Guimarães ${ }^{3}$, Giulio Gavini ${ }^{4}$
'Department of Endodontics, UFPR - Federal University of Paraná, Curitiba, PR, Brazil ${ }^{2}$ Department of Pharmacy, UFPR - Federal University of Paraná, Curitiba, PR, Brazil ${ }^{3}$ Department of Statistics, UFPR - Federal University of Paraná, Curitiba, PR, Brazil ${ }^{4}$ Department of Esthetic Dentistry, School of Dentistry, USP - University of São Paulo, SP, Brazil

Correspondence: Dra. Marili Doro Andrade Deonizio, Avenida Anita Garibaldi, 964, ap 1403 Torre B, 80540-000 Curitiba, PR, Brasil. Tel: +55-41-3253-4927. e-mail: marilidoro@yahoo.com.br

\begin{abstract}
This study evaluated the influence of apical patency, root filling removal technique and cleaning of the apical foramen, concerning the amount of debris extruded during root canal retreatment. Forty mandibular incisors were randomly assigned to 4 groups - GIM $(n=10)$, GIIM $(n=10)$, GIPT $(n=10)$ and GIIPT $(n=10)$, which were named according to leaving (I) or not (II) apical patency during canal preparation and filling removal technique (manual - $M$ or ProTaper system - PT). After filling material removal, each specimen of each group had the apical foramen cleaned by sizes 15, 20 and 25 instruments, generating 12 subgroups: GIM15, GIM20, GIM25, GIIM15, GIIM20, GIIM25, GIPT15, GIPT20, GIPT25, GIIPT15, GIIPT20 and GIIPT25. Extruded filling debris was collected by a Milipore filtration system, an HVdurapore, $0.45 \mu \mathrm{m}$ pore filter with a $25 \mathrm{~mm}$ diameter. The filters were weighed before and after the collection on an analytical scale $\left(10^{-5} \mathrm{~g}\right)$, and the difference was calculated. The mean weight of extruded filling debris was analyzed statistically by Kruskal-Wallis and Friedman ANOVA tests $(\alpha=0.05)$. The mean values found in the groups (in $\mathrm{mg}$ ) were: $\operatorname{GIM}(0.95 \pm 0.94)$, GIIM $(0.47 \pm 0.62)$, GIPT $(0.30 \pm 0.31)$ and GIIPT $(0.32 \pm 0.44)$. There was no statistically significant difference among any of the groups or subgroups $(p>0.05)$. ProTaper provided the smallest amount of extruded filling material, regardless of presence or absence of apical patency, followed by manual technique, without and with apical patency. Additional amounts of debris were collected during cleaning of the apical foramen, regardless of the instrument, presence/absence of patency or root filling removal technique.
\end{abstract}

\section{Introduction}

The primary reason for a negative outcome following root canal treatment is the persistence of bacteria within the intricacies of the root canal system. Therefore, the main goal of retreatment is to regain access to the apical foramen by complete removal of root canal filling material to facilitate the proper cleaning and shaping of the root canal system, so that the persistent periapical inflammation will be avoided (1).

In order to reach this goal, safe and efficient removal of gutta-percha (GP) from root canal systems is essential to achieve endodontic sanitization (2). During GP removal, endodontic instruments are usually forced in a way that the root canal filling materials, solvents, necrotic tissues, bacteria or irrigants may be pushed into the apical lesion. These apically extruded materials have been considered clinically responsible for postoperative inflammation and flare-up or even failure of apical healing $(3,4)$.

The technique for endodontic retreatment should make dentinal walls free of sealer and gutta-percha, while controlling the amount of apical extrusion (5-8). However, it has been reported that debris is indeed forced out during root canal preparation and retreatment, regardless of used technique (8-10) and remained in the apical third of the endodontic space $(8,11,12)$.
Disinfection, patency and cleaning of the apical foramen have been said to be necessary to regain access to the apical foramen, by the complete removal of root canal filling material in the apical third (13). The goal of patency is to maintain access to the foramen and avoid the apical blockage that changes the working length $(11,13)$. Buchanan (14) defined a patency file as small flexible K-file, which passively moves through the apical constriction without widening it.

Souza (13) supports the idea that the cemental canal should be included in root canal instrumentation, extending to the entire canal length. Thus, patency should be performed with an instrument that binds to the minor foramen, on the point where the apical constriction is supposedly located (CDC). From this point, the cemental canal presents divergent walls. It means that the binding file will bind solely to a portion of the foramen and it will not touch the divergent walls of the cemental canal; thus, its cleaning potential is limited. Because of this, the author suggested using two files of greater size to bind the CDC junction (minor foramen). One of the arguments against this procedure, however, is that a file that binds to the foramen might act in apical foramen transportation (15), as well as act like an embolus, increasing the possibility of debris to be inadvertently extruded beyond the apex (13). 
Nickel-titanium (NiTi) rotary instruments have also been used to remove filling materials from root canal walls, and various studies have reported their efficacy, cleaning ability and safety $(9,12,16,17)$. The ProTaper Universal system (Dentsply Maillefer, Ballaigues, Switzerland) has three retreatment files - D1, D2 and D3 -, which are designed with various tapers and diameters at the tip (\#30/0.09; \#25/0.08 and \#20/0.07) for filling removal. Similarly to ProTaper's $\mathrm{S}$ and $\mathrm{F}$ series, these instruments have a convex cross section. D1 is designed to remove the filling material at the cervical third, D2 from the middle third and D3 from apical third (16-18). However, the action of this system in combination with apical patency and cleaning of the apical foramen on the apical extrusion during retreatment has not yet been investigated. The aim of this study was to evaluate the amount of debris extruded apically during retreatment by manual technique and ProTaper Universal system, with subsequent cleaning of the apical foramen in root canals, whether with or without prior patency.

\section{Material and Methods}

\section{Specimen and Canal Preparation}

After authorization from the Ethics Committee (number 585.122.08.07; CAAE: 2410.0.000.091-08), 40 extracted mandibular human incisors with similar lengths and diameters, a single root canal, fully formed apices, curvature of at least 20 degrees and no previous root canal treatment were used in this study. Residual tissue and calculus were mechanically removed from the root surfaces and $3 \mathrm{M}$ Sof-lex ${ }^{\mathrm{TM}}$ discs (3M ESPE, St. Paul, MN, USA) were used to polish the root surfaces. The crowns were flattened, so that root canals showed a standardized length of $20 \mathrm{~mm}$, measured by a digital caliper. The same operator conducted each experimental procedure.

Access cavities were prepared and the specimens were randomly separated in two groups: in one group $(n=20)$, a size $15 \mathrm{~K}$-file (Dentsply- Maillefer) was inserted into the canal with forward and reverse movements, exceeding $1 \mathrm{~mm}$ of the working length $(\mathrm{WL}=19 \mathrm{~mm})$; in the other group $(n=20)$, the procedure was repeated, but without exceeding $1 \mathrm{~mm}$ of the WL. In all teeth, the cervical and middle thirds of wall teeth were enlarged with 1 and 2 Gates Glidden drills (Dentsply-Maillefer). The apical thirds were prepared with a crown-down technique to a size 45 K-file $1 \mathrm{~mm}$ short of the apex, using $2 \mathrm{~mL}$ of $1 \% \mathrm{NaOCl}$ between each instrument and $5 \mathrm{~mL}$ 17\% trisodium EDTA as a final irrigation. In one group of teeth, after the size $45 \mathrm{~K}$-file had been used, the size $15 \mathrm{~K}$-file was used again, exceeding $1 \mathrm{~mm}$ of the WL to maintain apical patency.

\section{Root Canal Filling}

All root canals were dried with paper points and filled according to a lateral condensation technique. A master gutta-percha cone size 40 (Dentsply-Maillefer) was selected and tug-back was checked. AH Plus sealer (Dentsply DeTrey $\mathrm{GmbH}$, Konstanz, Germany) was mixed according to the manufacturer's instructions. The master cone was coated with sealer and positioned into the canal. Then, accessory cones were laterally compacted until they could not be introduced more than $5 \mathrm{~mm}$ into the canal. Buccolingual and mesiodistal radiographs were taken to confirm that all specimens had well-compacted fillings extending to $1 \mathrm{~mm}$ from the apex. Cones were cut $3 \mathrm{~mm}$ above the cementoenamel junction and the access cavities were filled with a temporary material (Coltosol ${ }^{\oplus}$; Vigodent, Rio de Janeiro, RJ, Brazil). All teeth were stored in an incubator at $37^{\circ} \mathrm{C}$ for 2 weeks to allow complete setting of the sealer.

\section{Filling Material Removal, Reinstrumentation and Cleaning of the Apical Foramen}

The groups were named GIM, GIIM, and GIPT, GIIPT, respectively, according to the presence or absence of apical patency (I and II) and removal of filling material manually (M) or using the ProTaper Universal System (PT). In groups GIM $(n=10)$ and GIIM $(n=10)$ the filling material on the cervical third was removed with Gates Glidden drills 3, 2 and 1 (Dentsply-Maillefer) at a depth of 13, 14 and $15 \mathrm{~mm}$, respectively. Sizes 60, 55, 50 and $45 \mathrm{~K}$-files were used sequentially, advancing $1 \mathrm{~mm}$ in the apical direction each. Final apical enlargement was obtained with 45 and $50 \mathrm{~K}$-files at $19 \mathrm{~mm}$. In groups GIPT $(\mathrm{n}=10)$ and GIIPT ( $n=10)$, root filling was removed using the ProTaper Universal System powered by an electric motor with 500 rpm (Endo-Plus; VK Driller Equipamentos Elétricos Ltda, São Paulo, SP, Brazil). D1 file was used at $13 \mathrm{~mm}$ and D2 file was used for filling material removal from the middle third at depth of $16 \mathrm{~mm}$. D3 file was used at $19 \mathrm{~mm}$ and final apical enlargement was performed with F1 (ISO 0.20), F2 (ISO 0.25) and F3 (ISO 0.30) files at $19 \mathrm{~mm}$.

Each group was divided into 3 subgroups named according to the file (size 15, 20 and 25) used for cleaning of the apical foramen sequentially, three times each, at 20 mm: GIM15, GIM20, GIM25, GIIM15, GIIM20, GIIM25, GIPT15, GIPT20, GIPT25, GIIPT15, GIIPT20 and GIIPT25.

Between each change of instrument, the canal was irrigated with $2 \mathrm{~mL}$ of $1 \% \mathrm{NaOCL}$ and final flush was performed with $5 \mathrm{~mL}$ of 17\% EDTA delivered by a plastic syringe (Ultradent, South Jordan, Utah, USA) with a 21 mm-long Navitip needle (Ultradent).

\section{Collection and Quantification of Filling Debris Extruded through the Apical Foramen}

Filling debris was collected in the same specimen at four moments: first, during root filling removal and final 
apical enlargement; second, third and fourth, during cleaning of the apical foramen with sizes 15, 20 and 25 files, respectively.

The crown and root of each tooth were completely isolated with a double rubber dam and a \#9 clamp, and dripped with ethyl cyanoacrylate (Loctite ${ }^{\oplus}$ - Super Bonder - Henckel Ltda, São Paulo, SP, Brazil) around the clamp and along the cementoenamel junction. The tooth was attached to a metallic chromium-plated device with two lateral screws that held it vertically, so that its apex could be coupled to the Millipore filtration system (Millipore Ind. e Com. Ltda, São Paulo, SP, Brazil), which was used to collect apically extruded debris. The filtration system is composed of a glass funnel, a borosilicate glass base, a neoprene stopper, an anodized aluminum clamp, and a 25-mm diameter and $0.45 \mu \mathrm{m}$ white pore filter (Millipore Ind. e Com. Ltda.). A $125 \mathrm{~mL}$ filtering flask with a side arm was clamped to a support rod. The system was connected to a vacuum pump.

At each moment of debris collection, the root apices were rinsed with $40 \mathrm{~mL}$ of distilled water, applied with a Luer syringe (Becton Dickinson Ind. Cirúrgica, São Paulo, SP, Brazil) using a hypodermic 30 -gauge $\times 8$-mm needle. The last $5 \mathrm{~mL}$ were used to rinse the internal walls of the glass funnel. After the external root surfaces had been rinsed, the filters containing extruded material were removed from the filtration system and placed in a vacuum desiccant with silica gel for three hours and taken to a room with controlled temperature and humidity.

The weight of extruded filling debris was calculated by the difference between pre and post-collection of the filters three consecutive times on an analytical balance $\left(10^{-5}\right.$ g) (Metller Toledo AG245, Switzerland) under controlled temperature of $20{ }^{\circ} \mathrm{C}$ and humidity of $45-50 \%$. The mean weight of extruded debris material was analyzed statistically by Kruskal-Wallis and Friedman ANOVA tests at $5 \%$ significance level.

\section{Results}

The means and the standard deviations of filling debris extruded in each group and subgroup (in $\mathrm{mg}$ ) is displayed in boxplots in Figure 1. There was no statistically significant difference ( $p>0.05$ ) among groups or subgroups. The total amount collected during all phases of filling material removal is presented in Table 1.

\section{Discussion}

This study evaluated the effect of maintaining apical patency during root canal preparation and root canal retreatment by manual and mechanical techniques, with

Table 1. Mean amount of total extrusion of filling debris of groups and subgroups

\begin{tabular}{lcc}
\hline Groups and subgroups & Mean $(\mathrm{mg})$ & $\mathrm{p}$ value \\
\hline $\mathrm{GIM}+\mathrm{GIM} 15$ + GIM20 + GIM25 & 1.66 & \\
GIIM + GIIM15 + GIIM20 + GIIM25 & 1.80 & \\
GIPT + GIPT15 + GIPT20 + GIPT25 & 0.89 & $\mathrm{p}>0.05$ \\
GlIPT + GIIPT15 + GIIPT20 + GIIPT25 & 1.07 & \\
\hline
\end{tabular}

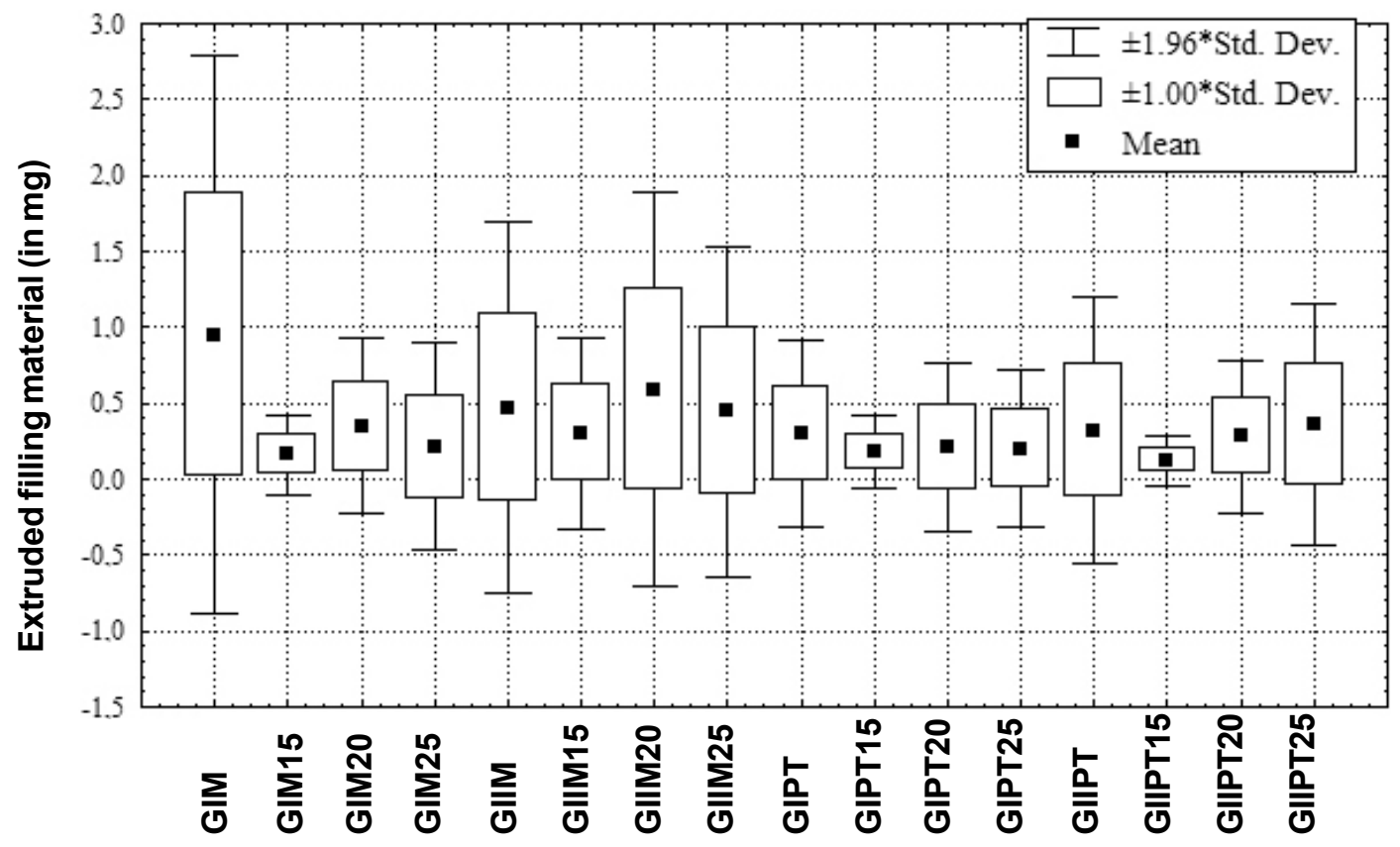

Figure 1. Boxplots representing average extruded debris in each groups and subgroups. 
subsequent cleaning of the apical foramen.

The concept of patency was used by Buchanan (14) and more recently by Souza (13). It has been considered a biological and intentional maneuver to eliminate an established infection in the apical segment. Authors like Cailleteau and Mullaney (19) affirmed that when patency was used to maintain the opening in the apical foramen the instruments varied from sizes 10, 15 to 20 .

Complete removal of pre-existing filling material from the canal is a prerequisite for a successful nonsurgical root canal retreatment (20), but remaining filling debris has been observed at different levels by different methodologies $(11,18,20)$. It would be therefore indicated to clean the apical foramen in endodontic retreatment. However, there is the possibility of overinstrumentation, which would force materials and debris into the periradicular tissues or promote apical transportation.

The apically extruded gutta-percha has an irregular aspect, with edges and tips, which can cause foreign body reaction or induce failure after retreatment (21). In addition, it may be accompanied by solvents, necrotic tissues, bacteria or irrigants, which might be introduced into the apical lesion (2).

The quantification of apically extruded debris during retreatment has been performed by visual observation $(6,9,16)$, collecting and weighing by an Eppendorf tube (5), acrylic resin container attached to the external root (10), aluminum crown (17) and papers filters (8). In this study, the Millipore ${ }^{\circledast}$ filtration system with a $25 \mathrm{~mm}$ diameter and $0.45 \mu \mathrm{m}$ durapore filter was used because it is simple, practical, affordable, reproducible and the filters are able enough to adhere any debris particles from root canal, but do not collect any amount of extruded liquid. The weight of extruded material was measured by an analytical balance in a room under controlled temperature and humidity conditions $\left(20{ }^{\circ} \mathrm{C}, 45-50 \%\right)$ because any change in these conditions may affect the measurements.

In this study, the groups with mechanical removal of filling material (GIPT and GIIPT) presented less amount of apically extruded debris than the groups with manual removal (GIM and GIIM), but there were no statistically significant differences ( $p>0.05)$, among any of the groups or subgroups (Table 1). Other authors found similar results $(4,5,17)$. Rotational movement and crown-down pressureless action, their design and friction on dentin wall can remove the GP towards the orifice more easily (22) and facilitate irrigation (23). By the manual technique, the instrument acts as a plunger, forcing the excised material to the periapex $(5,9,16,17)$.

During the cleaning of the apical foramen, some additional material was collected (Table 1 and Fig. 1). The literature has shown that it is impossible to remove all traces of GP/sealer from root canals with any retreatment technique $(7,12,18)$. Using larger instruments for this purpose can cause extrusion of significant amounts of debris (4) and more GP/sealer towards periapical tissues. According to Goldberg and Masson, 2002 (15) if a \#20 file is used for patency, the chance of transporting the apical foramen reaches $56.6 \%$.

The size $15 \mathrm{~K}$-file pushed out the least amount filling material through the apical foramen, regardless of the retreatment technique and presence or absence of patency (GIM15 - 0.15 mg; GIIM15 - 0.30 mg; GIPT15 - 0.18 mg; GIIPT15 - $0.12 \mathrm{mg}$ ). The size $20 \mathrm{~K}$-file extruded the most in all subgroups, except for GIIPT20, which extruded slightly less $(0.28 \mathrm{mg})$. The size $25 \mathrm{~K}$-file extruded more filling debris in GIIM25 (0.44 mg). Filling material may accumulate in the apical foramen and the instrument action during cleaning of this region can result in more debris extruded.

Hülsmann and Bluhm (16) demonstrated that ProTaper was efficient for the removal of gutta-percha during retreatment without apically extruded material. On the other hand, Somma et al. (9) observed more apical extrusion with the ProTaper system compared with the manual technique. However, those authors used a D3 instrument for apical preparation, whereas in this study the apical preparation was performed to the F3 instrument, which is considered effective for final apical enlargement (23).

In this study, F1, F2 and F3 were used to the working length to complete gutta-percha removal and cleaning of the canal walls. Barato-Filho et al. (18) in a histological analysis stated that the cleaning ability of these instruments is directly proportional to their diameter and suggest increasing the apical preparation to F4 and F5. However, F3 has 9\% increased taper and the corresponding diameter in the first $3 \mathrm{~mm}$ is: 0.39 (D1), 0.48 (D2) and 0.57 (D3).

In GIPT $(0.30 \mathrm{mg})$, apical patency provided less extrusion of filling material extruded. Anyway, when the patency was not done in GIIPT, the mean weight was similar (0.32 $\mathrm{mg}$ ). It probably shows that rotary instruments leave less filling material in the apical region.

Lambrianidis (24) found greater extrusion before apical patency with manual technique for root canal preparation, whereas Tinaz et al. (4) found more extruded debris with manual instrumentation in specimens with apical patency. However, no studies were found to compare results concerning root canal retreatment so far.

There is clinical and histological evidence that the presence of tissue-irritating foreign materials at the periapex, such as extruded root-filling materials, may affect post-treatment healing $(3,21,25)$. One suggested approach to solve the problem is to clean the apical region: a thin instrument, such as a size $20 \mathrm{~K}$-file, placed approximately $1 \mathrm{~mm}$ beyond the $\mathrm{WL}$ is the best and safest 
manner to attempt to push out the filling material that has accumulated at the foramen. Therefore, nonsurgical conventional root canal treatment may provide the relief of symptoms and retain a functional tooth. However, still some infection and inflammation may remain. Thus, as in dentinal portion of the canal, instrumentation of the cemental canal should be considered (25) and a size 20 K-file may cause apical transportation.

The results of this study showed that apical patency does not influence the amount of extruded filling material when using the Protaper Universal System, but it does influence the outcome by manual technique.

\section{Resumo}

Este estudo verificou a influência da patência apical, técnica de desobturação e limpeza foraminal na quantidade de material sólido extruido, durante retratamento endodôntico. Quarenta incisivos inferiores foram divididos aleatoriamente em quatro grupos - GIM ( $n=10)$, GIIM $(n=10)$, GIPT $(n=10)$ e GIIPT $(n=10)$ - nomeados de acordo com a realização (I) ou não (II) de patência apical durante o preparo de canais e a técnica de desobturação - manual (M) ou sistema ProTaper (PT). Após a desobturação, realizou-se a limpeza foraminal em cada espécime de todos os grupos com instrumentos \#15, \#20 e \#25, gerando 12 subgrupos: GIM15, GIM20, GIM25, GIIM15, GIIM20, GIIM25, GIPT15, GIPT20, GIPT25, GIIPT15, GIIPT20 e GIIPT25. 0 material sólido extruído foi coletado pelo sistema de filtração ¿ Millipore ${ }^{\circledast}$, com filtros de $0,45 \mu \mathrm{m}$ de poro e $25 \mathrm{~mm}$ de diâmetro. Os filtros foram pesados antes e após a coleta, em balança analítica de precisão $\left(10^{-5} \mathrm{~g}\right)$, e as diferenças foram calculadas. Os valores médios encontrados (em mg) foram: GIM $(0,95 \pm 0,94)$, GIIM $(0,47 \pm 0,62)$, GIPT $(0,30 \pm 0,31)$ e GIIPT $(0,32 \pm 0,44)$, sem diferença estatística entre quaisquer dos grupos ou subgrupos $(p>0,05)$. 0 sistema Protaper proporcionou a menor quantidade de material sólido extruido, independente da presença ou não de patência apical seguidos da técnica manual sem e com patência apical. Quantidades adicionais foram coletadas durante a limpeza foraminal, independente do instrumento utilizado, da presença ou não da patência apical ou da técnica de desobturação.

\section{References}

1. Ng YL, Mann $V$, Gulabivala K. A prospective study of the factors affecting outcomes of non-surgical root canal treatment: part 2: tooth survival. Int Endod J 2011;44:610-625.

2. Mounce R. Current concepts in gutta-percha removal in endodontic retreatment. N Y State Dent J 2004;70:32-35.

3. Nair PN. On the causes of persistent apical periodontitis: a review. Int Endod J 2006;39:249-281.

4. Tinaz AC, Alacam T, Uzun O, Maden M, Kayaoglu G. The effect of disruption of apical constriction on periapical extrusion. J Endod 2005;31:533-535.

5. Huang $X$, Ling J, Wei $X$, Gu L. Quantitative evaluation of debris extruded apically by using ProTaper Universal Tulsa rotary system in endodontic retreatment. J Endod 2007;33:1102-1105.

6. Bramante CM, Betti LV. Efficacy of Quantec rotary instruments for gutta-percha removal. Int Endod J 2000;33:463-467.

7. Wilcox LR, Krell KV, Madison S, Rittman B. Endodontic retreatment: evaluation of gutta-percha and sealer removal and canal reinstrumentation. J Endod 1987;13:453-457.
8. Imura $\mathrm{N}$, Kato AS, Hata GI, Uemura M, Toda $\mathrm{T}$, Weine $\mathrm{F}$. A comparison of the relative efficacies of four hand and rotary instrumentation techniques during endodontic retreatment. Int Endod J 2000;33:361366.

9. Somma F, Cammarota G, Plotino G, Grande NM, Pameijer $\mathrm{CH}$. The effectiveness of manual and mechanical instrumentation for the retreatment of three different root canal filling materials. J Endod 2008;34:466-469.

10. Uezu MK, Britto ML, Nabeshima CK, Pallotta RC. Comparison of debris extruded apically and working time used by ProTaper Universal rotary and ProTaper retreatment system during gutta-percha removal. J Appl Oral Sci 2010;18:542-545.

11. Nica L, Grigorie M, Rusu D, Anghel MM, Didilescu A, Stratul SI. Computer-assisted photomicrographic evaluation of root canal morphology after removal of the filling material during retreatment. Rom J Morphol Embryol 2011;52:443-448.

12. Fariniuk LF, Westphalen VP, Silva-Neto UX, Carneiro E, Baratto-Filho $F$, Fidel $S R$, et al.. Efficacy of five rotary systems versus manual instrumentation during endodontic retreatment. Braz Dent J 2011;22:294-298.

13. Souza RA. The importance of apical patency and cleaning of the apical foramen on root canal preparation. Braz Dent J 2006;17:6-9.

14. Buchanan LS. Management of the curved root canal. J Calif Dent Assoc 1989;17:18-25.

15. Goldberg $F_{1}$ Massone EJ. Patency file and apical transportation: an in vitro study. J Endod 2002;28:510-511.

16. Hülsmann M, Bluhm V. Efficacy, cleaning ability and safety of different rotary NiTi instruments in root canal retreatment. Int Endod J 2004;37:468-476.

17. Saad AY, Al-Hadlaq SM, Al-Katheeri NH. Efficacy of two rotary $\mathrm{NiTi}$ instruments in the removal of gutta-percha during root canal retreatment. J Endod 2007;33:38-41.

18. Baratto-Filho F, Leonardi DP, Zielak JC, Vanni JR, Sayão-Maia SM, SousaNeto MD. Influence of ProTaper finishing files and sodium hypochlorite on cleaning and shaping of mandibuldar central incisors - a histological analysis. J Appl Oral Sci 2009;17:229-233.

19. Cailleteau JG, Mullaney TP. Prevalence of teaching apical patency and various instrumentation and obturation techniques in United States dental schools. J Endod 1997;23:394-396.

20. Schirrmeister JF, Hermanns P, Meyer KM, Goetz F, Hellwig E. Detectability of residual Epiphany and gutta-percha after root canal retreatment using a dental operating microscope and radiographs - an ex vivo study. Int Endod J 2006;39:558-565.

21. Yusuf $H$. The significance of the presence of foreign material periapically as a cause of failure of root treatment. Oral Surg Oral Med Oral Pathol 1982;54:566-574.

22. Betti LV, Bramante CM. Quantec SC rotary instruments versus hand files for gutta-percha removal in root canal retreatment. Int Endod J 2001;34:514-519.

23. Vera J, Arias A, Romero M. Effect of maintaining apical patency on irrigant penetration into the apical third of root canals when using passive ultrasonic irrigation: an in vivo study. J Endod 2011;37:12761278.

24. Lambrianidis T, Tosounidou E, Tzoanopoulou M. The effect of maintaining apical patency on periapical extrusion. J Endod 2001;27:696-698.

25. Souza RA, Sousa YT, de Figueiredo JA, Dantas J da C, Colombo S, Pécora JD. Influence of apical foramen lateral opening and file size on cemental canal instrumentation. Braz Dent J 2012;23:122-126.

Received June 1, 2012 Accepted October 22, 2013 